\title{
Love as the core of the diaconal dimension of the church
}

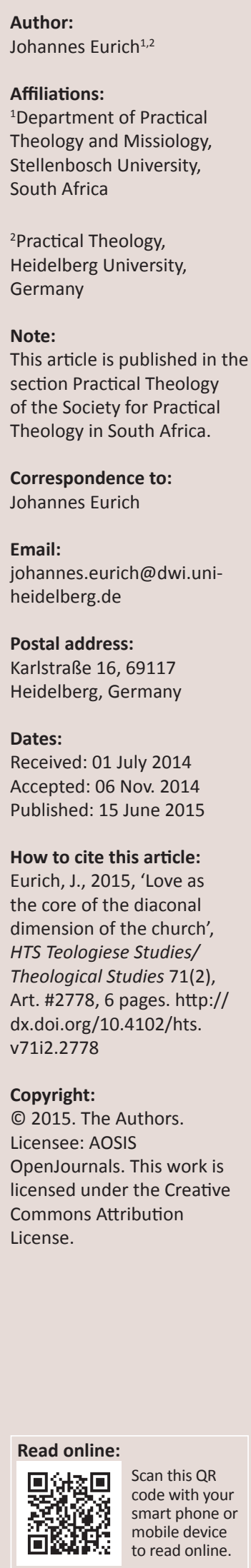

This article will discuss different understandings of love. In particular, two modern perceptions of love will be differentiated: love as consisting of individual, often inconstant, emotions between human beings, and a Christian understanding of love, which is often expressed through caring for other members of the community. Aspects of Christian love will then be examined in ethical terms, emphasising the relevance of love for the diaconal dimension of the church. Before one is able to help one's neighbour, one first has to be actively identified within the complex social structures of society. Next, the nature of diaconal action has to be defined and adapted to individuals who are in need, or who have become needy or been disadvantaged by society, for example, migrant workers, refugees or asylum seekers. A central aspect of diaconal action - in addition to meeting basic needs - lies in giving a voice to such individuals and in empowering them, including politically, to represent their own interests in public life.

\section{Introduction}

Many consider love to be one of the primary Christian characteristics. At the same time, it is often not clear what Christian love means and what actions should follow from such an attitude towards one's neighbour. Furthermore, the concept of love has taken on a vast array of different meanings in contemporary society. In this article I would like to present love as the core of the diaconal dimension of the church. In following God's command to love one another, Christians can play a significant role in addressing the challenges posed by the complex social structures of contemporary society. The context of my paper is the welfare society in Europe (which provides basic social security, even though the nature of the national welfare state differs from country to country). I know that in South Africa the context of poverty is very different. ${ }^{1}$ Yet I believe that one can learn from each other by comparing the ways social challenges are handled from a Christian perspective.

I would like to start by positing an understanding of love which aims at acting for the benefit of the other. This is contrasted in my first point to be discussed below with some contemporary notions of love portrayed in society today. I shall then tease out aspects of Christian love in ethical terms in order to show its relevance for the diaconal dimension of the church. The social structure of complex societies can often conceal the reality of people in need; hence the second point below addresses the question to whom should love be directed in a diaconal sense and what form diaconal action as a dimension of the church should take. The societal aspect will be taken up again in my third point to analyse the ways in which people become poor or needy in modern societies. As a result of this analysis, churches are called on to empower those who experience hardship in order to help them to speak up for themselves and for their voices to be heard in the public sphere. Thus, love understood as the diaconal dimension of the church also has political implications, which will be discussed in my last point below.

\section{Understandings and perspectives on love in a general sense}

In the New Testament, to love God and to love one's neighbour is understood as the fulfilment of God's law. In a well-known verse (1 Cor 13:13) the Apostle Paul adds love alongside faith and hope, and refers to it as the greatest of the three. Later, the early church father Ambrose would understand love as a Christian virtue. Although the Bible contains different ideas of love (agape, Eros, philia), one dominant Christian understanding of love is that it is a sincere and deep sympathy for another human being, often expressed through active forms of care. Not surprisingly, for Swiss New Testament scholar Ulrich Luz (2010), 'love' is the most distinctive and most common 'nota ecclesiae' in the New Testament: 
In it the 'vertical' and the 'horizontal' dimensions of the church are brought together: its life deriving from the reality and the mission of God or Christ and its social gestalt. (p. 415)

Love finds its realisation in the social gestalt of the church as part of the communion between Christians. In his work Sanctorium Communion, Dietrich Bonhoeffer (1963:195-205) refers to love in a similar way by also classifying the ecclesial community as a community of love in which all actions are conditioned by Spirit-inspired love. These two interpretations already show how love constitutes a key element of Christian attachment. This Christian communion proves itself to be 'a solidarity community founded upon the belief, and the acting and suffering for one another' (Schwöbel 2002:406). The nature of the action to be taken therefore raises the issue of the appropriate response on behalf of the neighbour.

When we consider perceptions of love that are widespread in society today, clear differences become apparent. The key element of love is no longer God's outpouring love, to which believers respond by sharing this love with their neighbours, but rather an individual world of fluctuating emotions. In modernity love becomes a projection screen for one's yearning for happiness in relationships. Frédéric Beigbeder, a French author and award-winning movie director, recently exclaimed in an interview: 'Love is not possible! Love is a lie!' (2012:12). Beigbeder perceives love as very romantic yet remains deeply cynical about its realisation. In his film L'Amour dure trois ans (Love lasts three years 2011) Beigbeder posed the question as to whether there could be a love that lasts longer than three years and suggests that he considers the question inherently wrong, for it is merely about feeling something at a particular moment. All that counts is the powerful feeling experienced in this moment, in which people are hopelessly at the mercy of this emotion, yet it does not last. Beigbeder appears to express what many people understand by love today: 'Nobody believes in God any longer, we have no utopias anymore. The last utopia we still have is love' (Beigbeder 2012:12).

Of course, there are also other notions of love apart from these. For instance, the meaning of love as a form of tender and deep attachment to another person, which can be distinguished by active care for the other and takes on the dimension of solidarity. In late modernity love for the neighbour is expected of the churches as agents of solidarity. Churches ought to take care of the poorest of the poor. Such convictions are still deeply embodied in society and I shall now turn to them in order to discuss love in ethical terms.

\section{Aspects of Christian love in ethical terms}

Who loves? Who will be loved? What distinguishes Christian love from other forms of love? When we consider the Christian command to love one's neighbour, we find that these seemingly simple questions cannot be answered that easily. I would like to work with a basic differentiation with regard to love which appears to me fundamental in relation to ethics. We can differentiate two levels of love: The first describes the emotional level of being moved, the inner emotional stirring which can, but not does have to, include an inner burning desire for another person in the early phase of falling in love. The second level refers to the propositional explication of what one understands love to be.

Before we are even confronted with the alternative between what we want to do and what we ought to do, the first level of perception consists of an indivisible unity between being inclined to and being connected to, which leads to an intuitive orientation to engage in a certain action or behaviour towards the other (cf. Fischer 2003:143f.). Thus, we can say that this intuitive orientation towards and sense of connection with another person is based on the concrete experience gained in particular situations and this brings about a certain disposition to engage in certain forms of action and behaviour. This first level, however, needs to be differentiated from the second level, by the propositional explication which is fundamental to the understanding of love and determines what love, in its intuitive impulsivity, is aimed at. Love in the Christian understanding-like the sphere of morality - can only be understood by the interlacing of these two levels. From the point of view of theological ethics, the substance of love becomes concrete - as perception of my neighbour, of my brother, of the fellow-creature, et cetera from the Christian symbolisation of life's reality on a 'level of intuitive, prepositional moral perception' (Fischer 2003:143). With this in mind, the Christian tradition has sought to tease out the full implications of the term love for the moral focus of Christian existence.

Faith and love are inextricably linked. Martin Luther (1883) defined this in a wonderfully concise way when he wrote that:

[A]ll deeds are to benefit the neighbour, because everyone can live from his faith and therefore can provide his life and his deeds to serve his neighbour freely and out of love. (WA VII:35)

The point is the liberty of the believer who has been freed by God from worrying about his own existence that enables him to focus his care on his neighbour out of love. However, what is the good? How is it determined?

The interrelated nature of the above-mentioned two levels is thus based on the fact that the first level of this intuitive 'being oriented towards' needs to be examined constantly to determine whether 'love's sense of orientation is indeed preserved, and the person does not intuitively act in a way that harms another due to problematic consequences and side-effects of love's impulsivity' (Fischer 2003:145). Here, it becomes clear that Christian love depends on the critical ability of reason and its substance, and is determined in a discursive way on the second level. Can the first level then be disregarded? The answer is no, because at the same time, the neighbour is apprehended and accessed intuitively on the first level through direct experience. This can occur, for example, in a personal encounter, or through the medium of a picture, or in a narrative way. As a result the first level also 
plays a role 'in determining what will benefit the neighbour. Both levels are thus inextricably interlinked' (Fischer 2003:145f.).

As a result, according to a Christian understanding, love is oriented towards the consequences of an action. Johannes Fischer points out that 'one should not think of the usual meaning associated with consequentialist ethics. ${ }^{2}$ Such ethics imply that an action receives its goodness from the results of this deed. The Protestant faith has a different approach: Luther takes the individual believer and his or her faith as his starting point. 'Deeds receive their goodness from faith' (Fischer 2003:146). Luther (1883) described this pointedly in the sermon on 'good works' in the following way:

The first and the highest, most precious deed is faith in Christ (...). For from this deed all other deeds must emanate and receive the influx of their goodness like a new tenure. (WA VI:204)

However, if the goodness of an action is not contingent on the consequences of this action, but on the individual believer, an action will radically lose its moral basis:

For love that comes from the liberty of faith does what it does, not because it is 'good' or because it represents a moral value, but entirely because of whom this love is devoted to. (Fischer 2003:146, emphasis original)

It is important to note that this understanding differs from consequentialism. In the Christian understanding consequentialist ethics apply in a limited form only: What makes an action good depends on whether all of life is oriented in terms of faith and love. These state that the consequences of an action should benefit my neighbour:

What 'benefit[s] my neighbour' - and [is] therefore in the service of love-means, [that it] is not fixed and unchanging for all times, but must be re-examined and rediscovered in each era in the light of changing cultural and social circumstances. (Fischer 2003:146)

\section{Christian love at the core of diaconal action}

Christian love has a cross-border dimension, as we already hear in the narrative of The Good Samaritan (Lk 10:25-37). One central point of that narrative is transcendence of an ethnocentric ethos in which the moral rules of an ethnic group were applied only to members of that particular group. Members of other ethnic groups were not included - or only in exceptional cases. The narrative of the Good Samaritan goes beyond such boundaries in such a striking way that Gerd Theißen (1998:391; 1999:50ff.) emphasises the movement of Christian love towards a universal ethos of support as its distinctive feature. With this in mind, Rebekka Klein (2012:36) recently characterised charity as a 'transgressive norm' in an article in the Zeitschrift für Evangelische Ethik. What makes 'The Good Samaritan' narrative fascinating is how two peoples' perception of the needy individual, leads to different behavioural consequences compared to the perception of the third man, the Samaritan, who breaks with the expectations of society.

Obviously, the perception of the 'other' as a person comes before love (for this person), or more accurately, before performing acts of love (for this person). This links up with the first level of love, the level of intuitive moral perception. The question: 'But who is my neighbour?' - which is also asked at the beginning of the narrative of the Good Samaritan - is therefore not only a question about the addressee of the help, which is often answered as follows: "The one that needs us is our neighbour' (Trillhaas 1965:263). This question, in fact, points out that the offer of love always needs to be applied as a general code of behaviour in a concrete context, and that there will be substantive scope for interpretation if this code of behaviour is implemented (Klein 2012:40). According to Klein (2012:41) the scribe's question could be rephrased to: 'How should I identify my neighbour?' The narrative then shows that the Samaritan's help was offered spontaneously, because of his perception of the concrete situation.

This analysis presents a problem for diaconal studies. For today the question of who my neighbour is cannot simply be answered by 'anyone who needs help'. There is room for interpretation, which changes how people respond to the situational perception of hardship. For example, the security provided by a social welfare state which has taken on the provision of many forms of support, thus ensuring help, is available in such a wide array of situations that this may restrain one from helping others. As a result, many drivers will drive past an accident site not only when they see an ambulance is at hand, but also when no ambulance has arrived yet, since they know that the duty to provide aid has been delegated to professional service providers (paramedics, police, tow truck services). Nonetheless, many accident victims remain reliant on first aid assistance from bystanders until an ambulance arrives. The knowledge that social assistance will be provided by rescue services can hinder a spontaneous reaction to provide help in response to the perception of hardship - this again underlines that the first level of intuitive perception draws its certainty as to content from the second level of rational interpretation, where we address the other human being as a fellowcreature, as brother or sister.

Christians may help, like the Samaritan, even if this goes against societal expectations and thus leads to a lack of understanding from others. However, what is the problem then? It lies in the question: Who are the ones who have fallen into the robbers' hands today? One can, of course, quickly list many examples of cases of emergencies which happen in the private domain and affect entire regions. There is a strong solidarity on behalf of fellow citizens affected by natural tragedies such as a tsunami or flooding. Modern welfare systems help countless people in distress or with special needs. From a scientific and diaconal perspective, however, one will also want to tend to the poorest of the poor, to the people on the fringes of society, to the fellow citizens who 
lead hidden lives in the twilight zones unnoticed by others. Poverty, HIV et cetera, are well known, but at the same time are they neither adequately represented in public life and discourse, nor is there an adequate response to such evils.

In order to identify and comprehend social predicaments, the first step is to promote their visibility. If we take the example of poverty, this means making visible the enormous extent and implications of poverty, publicising the multi-layered problems of those who are typically thrown together under the collective term poor. The collective term suggests a loss of respect for the individual and a contempt for and failure to notice the individual predicaments of those thus labelled. ${ }^{3}$ 'For desperate situations in contemporary societies can be invisible and may disappear as a result of bureaucratic administration, cultural processes of stigmatisation, and displacement' (Maaser 2013:34). While both individual situations of hardship and discourses of scandalisation appear in the media from time to time, these only produce periodic, short-lived expressions of deep sorrow. In principle, such processes are also subject to complicated entanglements between the public arena of politics and the media in which 'whatever is not communicated socially, does not exist in a way' (Maaser 2013:34.). One could also say that only the hardship which is displayed and noticed in the public arena is actually perceived as existing in society. Whoever is not placed at the forefront of public attention in this way will not be provided with adequate attention and care.

Thus, diaconal action as expression of Christian love in complex societies not only means meeting someone's basic needs, but can also mean to learn to perceive the hardship, to look for and to find the suffering neighbour in the first place. Michael Winkler recognises new forms and 'formations of isolation', even for rich societies such as the Federal Republic of Germany: active isolation is being replaced by the social invisibility of the isolated. The dilemmas of entire segments of society are not being addressed. And finally, the isolation itself moves 'out of focus while being watched. It becomes visible as distress, which is being overlooked at the same time' (Winkler 2005:110). As a result, the isolated are 'right in the middle of things, but even less worth than socially worthless: they are, quite literally, existences that don't exist' (Winkler 2005:113). This may apply to groups of people such as migrant labourers, refugees or asylum seekers, who come to other countries without legal papers, but also to other permanent groups of people such as (old) people with disabilities and/or special needs.

Perhaps a parable can be applied to this situation. Like the shepherd who seeks the one lost sheep (Mt 18:12-14), diaconal action as expression of Christian love seeks those who are lost in the confusion of modern societies; it goes to the fringes of the social order, and crosses boundaries in order to find those whose fate remains unmentioned within the grey zones and rifts of differentiated societies. It is worth pointing out in passing that this has consequences for the church as well: We must step out of the walls of our own church community towards a form of community work that reaches out. The option for the excluded becomes real in the street, not in sacred halls (cf. Richard 2004). Gustavo Gutierrez (2009:30) has also indicated that 'to be a neighbour' does not say anything about physical closeness, but is an active act: '[T]he result of taking action, of approaching.'

\section{Political aspects of love as an expression of the diaconal dimension of the church}

'How can I approach my neighbour' can firstly be translated as: 'Who is perceived in what way by whom and how is it interpreted?' In the context of help from social security aid this also means: 'Who is actually classified as particularly needy and who determines what a need is?' These questions may be answered with reference to a car accident where the occupants are clearly identified as emergency cases because of their injuries. At the social level, however, the answer to this question is not so apparent at all. The way it is answered is already a factor in itself, which decides upon social hardship (see discussion below on who defines what poverty is). Churches often react and help those whose situation cries out for help (cf. Eurich \& Hübner 2013). Of course, this is a very valuable contribution which is to be acknowledged. However, I noted above that social hardship is not as obvious as one might imagine. Therefore the questions: 'Who interprets social emergencies?' and 'Who has the power to decide which socio-economic conditions are to be considered as requiring assistance?' are gaining exceptional importance. Here love has a specific function and - at the same time reaches a significant limit.

Firstly, with regard to its specific function: Love now requires 'developing or newly implementing a sensorium for the disadvantaged (people) of the legal systems', by taking the neighbour's concrete needs into account, and by being oriented towards the neighbour's best interests (Schmidt 2003:34). Love wants to perceive the other as fellow creature, as human being, whom God loves and who is entrusted to us as a human being in order to love him. Love will treat the legal system from the perspective of the disadvantaged by means of this sensorium, thus becoming a critical corrective to such a system (Schmidt 2003:34). This is the specific function of love in the formation of and the debate about the provision of modern social services. In other words: Christian love will insist that social participation of excluded people will be achieved step by step.

This requires that the diaconal dimension of the church as expression of Christian love always has to be political as well. This insight is not anything new. The Old Testament had already formulated the knowledge that love always remains associated with the acting subject; but it also conveys the idea that the law constitutes the right of the person concerned, of the potential victim. 'According to the biblical tradition, 
this right should not just be based (only) on sometimes unsteady love, much less on the love of the influential and powerful' says the Old Testament scholar Frank Crüsemann (2003:42). This still holds true today. Caring for people in need is a characteristic of Christian love. This love presses for addressing the causes of social despair, and therefore will always have to become politically active as well, if for no other reason than to make despair publicly visible. As a result, diaconal acting as expression of this love cannot be confined to the church of Jesus or to acts of mercy. This is a significant limit of love or of acts of mercy out of love. Rather, ' $[t]$ he love of today is the justice of tomorrow' (Wolf 1972:136). Love must get involved politically for the benefit of the ones affected in order to safeguard their rights and to retain their dignity.

What does such a political-diaconal commitment look like that is close to the affected people? To illustrate this I would like to turn to an example from Austria, to a campaign waged by the Diaconia of Austria: 'We aren't humble petitioners, we want respect!' (Schenk 2013:242). This was the message of the participants to Austria's first meeting of people in poverty. The meeting took place 2006 in Vienna under the slogan 'Becoming visible'. The unemployed, sellers of newspapers for the homeless, people with mental disabilities and special needs, as well as single mothers and immigrants met for three days to share some thoughts on common strategies against poverty, to point out their concerns and to discuss solutions. 'What becomes visible is our daily experience, our skills and strengths - and what we demand in order to improve our situation' (Schenk 2013:242). This meeting was followed by another campaign at the Second Poverty Conference in Linz in 2007, at which 100 cardboard figures symbolising the struggle of a life under conditions of poverty were set up in the city centre. The figures told the life stories of the people, as well as their wishes and hopes for their lives. Furthermore, the most recent figures were published about the increasing number of welfare recipients, unemployed, low-income employees, children in poverty, and about the situation of people with a mental impairment. 'It was a step out in the open. A step to break the silence, as a participant said' (Schenk 2013:243). The meeting in Linz also presented the opportunity for direct contacts with political leaders and decision-makers of various political parties and for discussions about topics relevant to poverty, such as a method of measuring poverty (Moser \& Schenk 2010).

Why are these campaigns important? According to Lister, the term poverty is not to be understood as a definition, but as a concept, which describes the relationship between the poor and the not poor (Lister 2004:100). The concept serves to distinguish people living in poverty as 'the others'. For that, Lister (2004:101) uses the term othering to describe the process in which people in poverty situations are denied the right to define their situation. As a result, they are forced to view themselves from the others' perspectives (i.e. the perspectives of the rich), thus becoming people that are 'the others' (Wyller \& Heimbrock 2010). In the process entirely different people are classified as 'poor' for statistical reasons, and this classification is considered more significant than all differences that exist between impoverished pensioners, single mothers, people with a migration background, the unemployed and people with a mental impairment.

The decision on who is socially 'the others' relates to the issue as to who has the power of interpretation. This (power) lies almost exclusively in the hands of people who are not directly affected by marginalisation or exclusion: journalists, scientists, social experts, civil servants and politicians. Accordingly, social inequality, and thus poverty as well, are represented and interpreted in public, according to the sociologist Eva Barlösius (2005), primarily by diagrams, statistical data, categorisations and classifications as well as by poverty reports, which convey a certain concept of society. The views of the people affected by poverty are ignored in it. Poverty conferences organised by poor people like the ones in Austria, try to modify questionnaires (used in other categorisations and classifications) and to speak for themselves in public. By doing so, they start to win basic forms of public representation, from which they are usually excluded.

What do campaigns such as 'Becoming visible' by the Diaconia of Austria have to do with Christian love? If one wants to paraphrase the term 'love', then 'deep appreciation' can be an excellent choice as a synonym. To love a person means to show him or her deep appreciation. This starts off with respect for the other person and his or her life story. It does not command the other, but becomes aware, listens, accommodates. It gives meaning, namely by taking seriously the meaning people give their lives through telling their own story and refusing to become categorised by others. Consequently, the diaconal work of the church should also encompass the opportunity for people in poverty to express their own lives, especially in public, and to experience themselves as being self-determined - at least at this first stage. This first step is not only a step out of the silence, but also a step forward to regain meaning for their lives. This understanding of love, therefore, is also a renunciation of all forms of paternalistic love, which tells others what is good for them. At the same time it is clear that this first step will be a waste if the fight against poverty is not waged at the political-structural level (Leiprecht 1997). Now is the time to run public events organised by the poor (respectively by the affected people themselves), to argue about definitions, criticise publicly and initiate public campaigns. Therefore, diaconal action inevitably has a political dimension in order to stand up for the rights of disadvantaged and excluded people. This remains a challenge for the diaconal dimension of the church.

\section{Conclusion}

The commitment to love makes diaconal action, time and again, take the view from below and tend to the people who are not able to find their own place in society and are or will be marginalised in the highly complex interactions of modern 
societies, be it as a result of their lack of education, physical disability or because of structural problems which ostracise the individual from sectors of society. Love draws our attention to those people who do not fulfil - or do so only in a limited way - the prerequisites for cooperating in societies, and therefore cannot expect anything from a complex society, because they cannot participate in it. The reference point of love is the well-being of one's neighbour. It directs its attention to the needs of the other and by doing so contributes towards his or her concrete situation to formalised procedures such as public debate. It wants to change concrete conditions that prevent people 'in elementary ways from developing their full potential in life' (Fischer 2003:152). It wants people to experience themselves as valued and significant, and to believe in their dignity. It wants to maintain the subjectivity of the affected; it wants to enable people 'to be - and have the authorisation to be - concerned about themselves'; it wants 'to create space ... for the ostracised, in which they become visible at least to themselves' and 'to open up and create opportunities for the subjects to live and to learn and to form subjectivity $\ldots$ by offering them space to do so' (Winkler 2005:125). With this, deeds of love are an expression of the diaconal dimension of the church that can contribute towards a humane society - this may not be much in the light of all the social predicaments, but to the affected individuals it may mean everything.

\section{Acknowledgements Competing interests}

The author declares that he has no financial or personal relationships which may have inappropriately influenced him in writing this article.

\section{References}

Barlösius, E., 2005, Die Macht der Repräsentation: Common sense über soziale Ungerechtigkeit, VS Verlag, Wiesbaden. http://dx.doi.org/10.1007/978-3-322 80747-2

Beigbeder, F., 2011, 'L'amour dure trois ans', motion picture, EuropaCorp Distribution, Paris.

Beigbeder, F., 2012, 'Es ist heute leicht, ein Zyniker zu sein. Sogar in der Liebe. Frédéric Beigbeder über Romantik und Politik, die Vereinigten Staaten von Europa und die Frage, ob man mit 25 schon ein Genie sein soll', Süddeutsche Zeitung, 19 July, p. 12.
Bonhoeffer, D., 1963, Sanctorum Communio. eine dogmatische Untersuchung zur Soziologie der Kirche, 4th edn., Kaiser, München.

Crüsemann, F., 2003, 'Soziales Recht und freiwilliges soziales Engagement im Alten Testament', in H. Schmidt \& R. Zitt (eds.), Diakonie in der Stadt: Reflektionen Modelle - Konkretionen pp. 25-43, Kohlhammer, Stuttgart.

Eurich, J. \& Hübner, I. (eds.), 2013, Diaconia against poverty and exclusion in Europe. Challenges - Contexts - Perspectives, Evangelische Verlagsanstalt, Leipzig.

Fischer, J., 2003, 'Jenseits reiner Normativität. Skizze einer theologisch-ethischen Annäherung an die Gerechtigkeitsthematik', in P. Dabrock, T. Jähnichen, L. Klinnert \& W. Maaser (eds.), Kriterien der Gerechtigkeit: Begründungen, Anwendungen, Vermittlungen, pp. 137-156, Kaiser, Gütersloh.

Gutierrez, G., 2009, Nachfolge Jesu und Option für die Armen: Beiträge zur Theologie der Befreiung im Zeitalter der Globalisierung, Academic Press, Stuttgart.

Klein, R., 2012, 'Nächstenliebe als transgressive Norm: Situationsethik und die Heuristik kontextueller Verhaltensorientierungen', Zeitschrift für Evangelische Ethik 56, 36-48. http://dx.doi.org/10.14315/zee-2012-56-1-36

Leiprecht, R., 1997, 'Soziale Repräsentation, Diskurs, Ideologie, Subjektiver Möglichkeitsraum. Überlegungen zu Konzepten in der Rassismus- und Nationalismusforschung', in Cleve, G., Ruth, I., Schulte-Holtey, E. \& Jäger, S. (eds.), Wissenschaft, Macht, Politik: Interventionen in aktuelle gesellschaftliche Diskurse, pis. 70-85, Westfälisches Dampfboot, Münster.
pportion

Lister, R., 2004, Poverty, Polity, Cambridge.

Luther, M., 1883, in J.K.F. Knaake \& P. Pietsch (eds.), Werke: Weimarer Ausgabe (WA): Kritische Gesamtausgabe, 1883-2009, Bölau Verlag, Weimar.

Luz, U., 2010, 'Ortsgemeinde und Gemeinschaft im Neuen Testament', Evangelische Theologie 70(6), 404-415. http://dx.doi.org/10.14315/evth-2010-0604

Maaser, W., 2013, 'Gemeinnützige Wohlfahrtsverbände zwischen normativem Selbstverständnis und operativen Zwängen', in J. Eurich \& W. Maaser, Diakonie in der Sozialökonomie: Studien zu Folgen der neuen Wohlfahrtspolitik, pp. 19-39, Evangelische Verlagsanstalt, Leipzig.

Moser, M. \& Schenk, M., 2010, Es reicht! Für alle! Wege aus der Armut, Deuticke, Wien.

Richard, P., 2004, La Fuerza Etica y Espiritual de la Teología de la Liberación - en el Contexto Actual de la Globalización, Departamento Ecuménico de Investigaciones, San José.

Schenk, M., 2013, 'Active agents as a new model of social advocacy: Participation and self-organisation of people experiencing poverty', in J. Eurich \& I. Hübner (eds.), Diaconia against Poverty and Exclusion in Europe: Challenges - Contexts Perspectives pp. 242-254, Evangelische Verlagsanstalt, Leipzig.

Schmidt, H., 2003, 'Gerechtigkeit und Liebe im Dienst der Versöhnung: Zum Ethos diakonischen Handelns und Lernens', in N. Collmar \& C. Rose (eds.), Das soziale Lernen - Das soziale Tun: Spurensuche zwischen Diakonie, Religionspädagogik und sozialer Arbeit, pp. 27-38, Neukirchener, Neukirchen-Vluyn.

Schwöbel, C., 2002, Gott in Beziehung: Studien zur Dogmatik, Mohr Siebeck, Tübingen.

Theißen, G., 1998, 'Die Bibel diakonisch lesen: Die Legitimitätskrise des Helfens und der barmherzige Samariter', in G. K. Schäfer \& T. Strohm (eds.), Diakonie - biblische Grundlagen und Orientierungen, 3rd edn., pp. 376-401, Diakonie - biblische Grundlagen und Orientierungen, 3rd edn., pp. $376-4$.
Diakoniewissenschaftliches Institut der Universität Heidelberg, Heidelberg.

Theißen, G., 1999, 'Universales Hilfsethos gegenüber allen Menschen? Neutestamentliche Wurzeln der Diakonie', in A. Götzelmann (ed.), Einführung in die Theologie der Diakonie, pp. 34-54, Heidelberg Lecture Series, Heidelberg.

Trillhaas, W., 1965, Ethik, 2nd edn., Töpelmann, Berlin.

Winkler, M., 2005, 'Formationen der Ausgrenzung', in R. Anhorn \& F. Bettinger (eds.), Sozialer Ausschluss und soziale Arbeit, pp. 107-127, VS Verlag für Sozialwissenschaften, Wiesbaden.

Wolf, E., 1972, 'Zur rechtstheologischen Dialektik von Recht und Liebe', in E. Wolf, Rechtstheologische Studien, pp. 115-136, Klostermann, Frankfurt am Main.

Wyller, T. \& Heimbrock, H., (eds.), 2010, Perceiving the Other: Case studies and theories of respectful action, Vandenhoek \& Ruprecht, Göttingen. 